\title{
GLOBALIZATION, INTERNATIONALIZATION AND EDUCATION: WHAT IS THE CONNECTION?
}

\author{
Kyria Rebeca Finardi ${ }^{1, a^{*}}$, Ramón Andrés Ortiz Rojo ${ }^{2, b}$ \\ ${ }^{1}$ Rua Raul de Oliveira Neves, 295 ap. 608, Vitória, ES, CEP. 29092220, Brazil \\ ${ }^{2}$ Rua Raul de Oliveira Neves, 295 ap. 608, Vitória, ES, CEP. 29092220, Brazil \\ akyria.finardi@gmail.com ${ }^{\mathrm{b}}$ raor72@gmail.com \\ ${ }^{*}$ Corresponding author
}

\begin{abstract}
The aim of this study is to reflect about the interconnectedness of globalization, the internationalization process of universities and the construction of social capital through education in emerging countries. The study is based on the assumption that the inclusion of English as an international language as well as courses on globalization in the curriculum of higher education courses is necessary to drive the development of social capital. The study analyzes the internationalization process in general and of the Business Administration Course in particular of two Brazilian universities in different contexts, a public and a private one. Results of the study suggest that one of the main challenges in the development of social capital in higher education in Brazil is related to the lack of linguistic proficiency in English to aid the internationalization process of education with the consequent inclusion of these countries in the globalized world and top ranked institutions.
\end{abstract}

Keywords: Globalization, Internationalization, Education, Social Capital.

\section{INTRODUCTION}

One way to view globalization is as a fundamental shift in people's time and space scales linking distant communities and expanding the reach of power relations across borders [1]. When these borders refer to education it comes as no surprise that globalization has deeply affected higher education. More specifically after WWII, three major changes caused by globalization can be observed in higher education: first, new models of higher education reinforced by the new political world order emerged and university education has been transformed from elite education to mass education; second, the rapid growth of student enrolment in the 1960s and the 1970s has been cited in recent decades as indicating a new stage of higher education with more diversity and patterns of higher education being observed across countries; third, these changes can be observed in four aspects of contemporary higher education, namely, the match or mismatch between higher education and the world of work; the importance given to research at the expense of education and services in post-modern universities and the emphasis on competition and internationalization of higher education institutions[2]. Another phenomenon that has been observed in tertiary education is that its growth is highly correlated to the economic growth of a country [3].

In the globalized world and information era we live in today, there seems to be a broad consensus among educators, sociologists and economists that the following factors are impacting on modern life [4]: the spread of information and communication technologies (hereafter ICTs) [5]; the access to ICTs and information online [6] which is mostly in English in the case of scientific publications [7] and the development of social capital afforded by the access to them $[5,6]$. 
The concept of social capital arose in the end of the twentieth century when a number of social scientists considered the role of interpersonal relations in human and social development [5]. Many of these scholars thought that the concepts of human capital and physical capital alone could not fully describe the phenomena of social and individual development in societies. Along with the concepts of human and physical capital is a category of social relations known as social capital.

Social capital is defined by Warschauer [5] as the capacity of individuals to accrue benefits by dint of their personal relationships and memberships in particular social networks and structures. For example, if a classmate provides information about a class project to a student who has missed class, that represents social capital. If a teacher or family member offers educational support to a teenager, that also represents social capital. If a company chief executive can be trusted to do what he or she says, that too is a form of social capital. Social capital accrues both to individuals and to communities, which benefit from the collective social capital in their midst. Social capital is not just a factor affecting human development, but a key variable affecting other inputs since it enhances investment in human and physical capital. For example, investments in education and training can be multiplied by the inputs of social capital as the strengthening of social ties enables people to better learn from and with others [5].

Globalization understood as the social and economic interdependence among people and countries affects and affects and is affected by the development of social capital and education. Another effect of globalization is the blurring of geographical and linguistic borders and the urgency to increase the educational level and social capital of the workforce to maintain a country's competitive advantage [7] or simply survival. In this scenario, new communications media and the capacity to appropriate social capital in the form of global skills -English and digital literacy being two of them [6] - so as to guarantee the possibility of internationalization, are changing the social, economic and political structure of societies across the world. Not surprisingly, these changes are affecting the way universities are dealing with the internationalization trend of education in this globalized and internationalized world.

According to Graddol [7] university curricula are undergoing extensive reforms in the search to upgrade the required skills and human capacity - or social capital in our view - to chase an ever-moving target in the ever-changing information era. A different model of education has emerged and requires individuals to keep pace with the fast update of information transforming it into knowledge through experience and critical thinking. As such, the role of formal education nowadays is more related to teaching how to learn rather than teaching what to learn. Teaching how to learn means, among other things, knowing where and how to access information and in that sense, Finardi, Prebianca and Momm [6] remind us that in a world where most of the information is transmitted in English and through clicks, being digitally literate and having some proficiency in English are passports to access information online. Put simply, the role of English in the curriculum is no longer that of a foreign language but rather that of an international and instrumental language and lately of an academic language in tertiary education as well [9].

Still according to Graddol [7], one feature of education in the postmodern world is its fragmented nature. We can say that formal education and validation count less than actual knowledge in this post-modern scenario. The advent of globalization and internet are changing the way people deal with information and knowledge. Post-modern people are becoming more autonomous in the search and transformation of information into knowledge and one example of this trend are the massive online open courses (MOOCS) available to meet learners' needs [10]. Unfortunately, not all universities have adapted their curricula to reflect this fragmented nature of knowledge to become more flexible and attractive to post-modern students. In Brazil, for example, students select the degree before they start the undergraduate course and once they select, for instance, to study medicine, the curriculum for that course is fixed and does not allow flexibility or change. If a medical student wants to take a philosophy course he or she will have to drop out of medical school and take the university entrance examination test again for another degree in order to study philosophy at university. As this paper intends to show, emerging countries such as Brazil are adapting to this new trend of higher education with different approaches and internationalization agendas.

A possible interpretation of the rise of a new model of education suggests that private sector providers and higher education planners are moving rapidly to define and position global markets with new institutional forms derived from global corporations. This model seems to serve the private for-profit educational model well in developed countries though it may have to be revised in emerging countries where the educational context is somewhat different. That ist he case of Brazil where the difference between public and private education is clear-cut: whereas public institutions are universal and non-profit, private institutions are all for profit. Globalization affects higher education in both positive and negative ways [10]. One negative effect of globalization on higher education in an emerging country observed in the Brazilian tertiary system is the increase of student enrolment in private universities. According to the latest statistics, less than $3,5 \%$ of Brazilians (almost 7 million) are enrolled in higher education institutions, $73,7 \%$ of whom are in private and 
$26,3 \%$ in public institutions. Another negative effect of globalization on education observed in Brazil is the fact that English as a foreign language is not a mandatory course in public schools with the consequence that private language institutions which offer English as a foreign language classes abound in Brazil creating a social gap between those who can afford to learn English and those who cannot.

The trend for more autonomy and digital and English literacy are perhaps positive effects of globalization and are even more evident because of the dominance of English-speaking universities (not by chance some of which are the same universities to offer MOOCS) as can be seen in the ranking of the world's top 20 universities provided each year by the Shanghai Jiao Tong University Institute reported in Graddol [7]. According to this ranking, around two-thirds of the world's top 100 universities are in English speakingcountries and the rest have adopted English speaking courses in their curricula. The 2005 list shown in Graddol [7] for the 20 top universities shows that all belonged to English speaking countries except for the Ecole Polytechnique in France, the Beijing University in China and the Tokyo University in Japan. Interestingly, these three exceptions have sites in English and offer courses in English.

This is one reason why English is used increasingly as the medium of instruction in universities across the world according to Graddol [7] and Smit and Dafou [9] who report on a study on the use of content and language integrated learning (CLIL) methodologies in universities across Europe as a way to internationalize these institutions. If an institution wishes to become a centre of international excellence, it needs both to attract students and researchers from around the world encouraging student mobility. Global competition is forcing the modern university to focus more on research becoming somewhat a semi for-profit organization $[1,2]$. Producing more research means circulating more research and that again is related to the role of English in academic publications and contexts. One example of how the language of publication relates to the construction of social capital is the fact that though Brazil has the 13th largest academic production in the world, it hardly affects the scientific community outside Brazil since most of the Brazilian academic production is in Portuguese. Not surprisingly and despite the criticism regarding the evaluation criteria of university rankings, there are no Brazilian universities ranked in the top 100 best universities worldwide.

Regarding the use of English as an academic language, Graddol [7] reviews the Bologna Process agreement signed in 1999 and which involved 45 countries in 2006 aiming at harmonizing university education within Europe using a common approach to levels and length of courses. The standardization of higher education is intended both to facilitate greater movement of students and to consolidate the internationalization process of institutions. Although the use of English in teaching is not a requirement of the Bologna Process, its use has been encouraged as it makes it easier for non-language specialists to carry out all or part of their undergraduate or postgraduate study in another country. In 2003-04 an estimated 1500 Master's programmes were offered in English in countries where English is not the first language. In Brazil and to the best of our knowledge only one of these courses was offered in English in the area of Applied Linguistics at the Federal University of Santa Catarina.

So as to have a glimpse of how a developing country is appropriating social capital in the form of education for a globalized world, the present study aims at looking at how two universities in Brazil deal with the internationalization and globalization trend in the Business Administration Course which is known to be a highly internationalized one. With that aim, the study looks at the curriculum of the Business Administration Course of two universities from different contexts in Brazil, a public and a private one, assuming that the private for-profit university would be more geared towards internationalization that the public one, due to the economic impact of receiving foreign students brought by globalization. The study also analyzes the internationalization policy and actions of the two institutions to suggest that higher education institutions in Brazil still face many challenges to go international, perhaps the biggest one of which is the lack of proficiency in English to enable exchange of faculty and students in a gradually growing borderless academic world.

\section{METHODS}

In order to analyze the appropriation of social capital in the form of internationalization of universities establishing the connection among globalization, internationalization and education, the study will contrast the Business Administration Course of two universities in Brazil, one private and one public. The study will look at the internationalization process (or lack of it) and curricula of these two courses in regards to the role of English and globalization in these curricula. The reason why the Business Administration Course, among all the possible courses offered by higher education institutions in Brazil was selected for this analysis is that this course is well known for its "internationalized" nature once business administrators are perhaps the professionals who first and foremost feel the impact of having to work in a globalized world. Regarding the choice of context, recall that public universities in Brazil are free whereas private universities charge fees 
and as such, we assumed that the need to internationalize and attract foreign students might be somewhat driven by different motivations in public and private institutions. Both universities analyzed in this study belong to the greatest chains of universities in their sector, namely, the public federal chain and the private chain, respectively. In what follows the two contexts will be described.

\subsection{The Public Non-Profit University}

The Federal University investigated is a public institution with three campi strategically located in three cities in a state of the Southeast region in Brazil. It offers academic and research activities in all areas of knowledge: 91 undergraduate courses, 60 postgraduate (46 master and 14 doctorate) programs. Tuition fees are not charged and scholarships may be available for undergraduate students enrolled in research or extension projects and for postgraduate students. Extension courses may have tuition fees. All classes are in Portuguese but the university has a Language Center that offers Portuguese language courses for foreigners as well English, Spanish, French, German and Italian as a foreign language courses for the community. International students who wish to apply for undergraduate courses have to take the entrance examination test (called "vestibular"). All the exams in universities in Brazil are held in Portuguese.

The university analyzed has an Office of International Affairs (OIA) which is responsible for the formulation of internationalization policies and the promotion and expansion of international actions advising the dean, the university central organs as well as education and research units. Among the OIA functions are the need to induce and consolidate the internationalization process, as a strategy for institutional growth and the improvement of academic activities; to advise all academic units regarding the implementation of international cooperation; to select, prepare and disclose information about programs and initiatives for international cooperation; to provide academic community with mobility opportunities; to support professors, researchers and students from foreign institutions to develop activities at or with the university; to encourage the implementation of agreements for research activities in collaboration with foreign institutions; to stay in touch with the Brazilian Foreign Affairs Ministry, as well as with international embassies, consulates, organizations and institutions and to promote actions whose aim is to give more international visibility worldwide for the university.

Students from countries in Africa, Latin America and Caribbean which maintain cooperation agreements with Brazil may take part in the Program for Partner Undergraduate Students (PEC-G, in the Portuguese acronym) which is a cooperation program between Brazil and countries in Africa, Latin America and Caribbean and whose goal is to give young students from these countries an opportunity to undertake their full undergraduate studies at Brazilian universities.

In terms of post-graduate mobility and scholarships the PAEC-OEA scholarship program launched by the Organization of American States (OEA in the Portuguese acronym) and the Coimbra Brazilian Universities Group (GCUB in the Portuguese acronym) with the support of the Education Office of the Foreign Affairs Ministry in Brazil, offers 160 scholarships for masters' and doctorate programs in 19 Brazilian universities among which is the one investigated. The aim of the program is to boost academic mobility and the regional development of the Americas and in its first edition 53 students in the continent were given the opportunity to earn their masters' degree in Brazil. Of course the main attraction of these programs is the fact that Portuguese is the language of mobility, though these programs are not helping Brazil in terms of increasing mobility with non-Portuguese speaking partners.

The most important internationalization program in Brazil is the Science without Borders Program (ScF in the Portuguese acronym) whose aim is to send Brazilian students and academics to non-Portuguese speaking countries (thus promoting mobility OUT). The program enables Brazilian students and researchers to be exposed to an environment of high competitiveness and entrepreneurship abroad and is focused in areas of strong industrial interest. The program seeks the consolidation, expansion and internationalization of science and technology with the consequent increase of Brazilian competitiveness through international mobility OUT. The ScF will award 101 thousand scholarships in four years to promote international exchange of Brazilian undergraduate and graduate students besides seeking to attract foreign researchers who wish to establish partnerships in or with Brazil in the focus areas of the Program. The CsF is by far the most important program for academic mobility OUT in Brazil.

After realizing that one of the major barriers to implement the CsF program in Brazil was the low proficiency level in English of Brazilian academics, the government launched the English without Borders (IsF in the Portuguese acronym) Program to help Brazilian university students improve their proficiency in English so as to be able to join the CsF program. The IsF is a joint effort of the Ministry of Education (MEC), the Higher 
Education Board (SESu) and the Agency for Improvement of Higher Education Agents (CAPES) and aims at improving the English language proficiency as well as of other foreign languages in Brazil ${ }^{1}$. As part of the IsF Program, the university analyzed in this study created a Center for English whose aim is to offer face-to-face and online courses for 360 students with CsF profile. The Center has 8 teachers and offers general English and Toefl preparation courses for students and faculty.

Besides these programs for student mobility, the public university investigated has partnerships with the following countries and universities: Germany - Deggendorf University of Applied Sciences, Justus Liebig Universität Giessen and Universität Siegen; Argentina - Universidade de Buenos Aires and Universidad Nacional de San Juan; Canada - Huntsman Marine Science Centre; China - Universidade de Chongqing; Ecuador - Escuela Superior Politécnica del Litoral; Spain - Universidad de Alcalá and Universidad de Córdoba; USA - University of Pittsburgh; France - École Nationale d'Ingénieurs de Brest, École Nationale d'Ingénieurs de Metz, École Nationale d'Ingénieurs de Saint-Étienne, École Nationale d'Ingénieurs de Tarbes, École Nationale d'Ingénieurs de Val de Loire, École Nationale Supérieure d'Arts et Métiers, École Spéciale des Travaux Publics du Bâtiment et de l'Industrie, École Télécom Paris Tech, Groupe des Écoles des Mines, Observatoire de la Côte d'Azur and the Université du Littoral Côte d'Opale; Italy - Istituto Politecnico di Milano, Università Ca'Foscari Venezia, Università degli Studi di Salerno and the Università degli Studi di Sassari; Mexico - Centro de Investigación Científica de Yucatán; Norway - Østfold University College, Portugal - Universidade de Aveiro, Universidade de Lisboa, Universidade de Algarve, Universidade do Minho and Universidade do Porto; Russia - Universidade Técnica de Kazan.

\subsubsection{Business Administration Course at the Public University}

The Administration Course at the public university investigated aims at forming professionals to organize, plan and control public organizations as well as private and social ones with a focus on the development of productivity and or profit searching for quality of life in general and specifically in the organization environments where the administrator acts.

The Administration Course lasts eight semesters and in general offers courses on Administration Theories, Economics, Human Resources, Accounting and Math. In the first semester the mandatory courses are: Introduction to Philosophy, Introduction to Social Psychology, Portuguese, Math 1 and General Sociology. In the second semester the courses are: Business Accounting, Statistics 1, Sociology Applied to Business, Theory of Organizations 1, Economics Theory 1. In the third semester: Organizational Behavior, Labor Law, Math 2, Organizations Theory 2, Economics Theory 2. In the fourth semester: Cost Administration, Materials Administration, Brazilian Economics, Statistics 2, Human Management. In the fifth semester: Administration Methods and Systems, Financial Budget Administration 1, Administration Practicum 1, Marketing Foundations, Environmental Management, Organizational Culture. In the sixth semester: Production Administration, Marketing Administration, Administration and Science, Financial Budget Administration 2, Administration Practicum 2, Human Management Seminar. In the seventh semester: Information Systems Administration, Business Ethics, Administration and Policies, Administration Research Project. In the last semester the only mandatory course offered is Integration and Research Seminar. There are many optional courses but none about globalization or international relations and or market. No ESP or CLIL courses are offered although, as previously mentioned, the public university investigated has a language centre which offers ESP and general English courses for the academic community as extracurricular courses.

\subsection{The Private For-Profit University}

The private institution investigated was founded 40 years ago and is one of the largest chains of private universities in Brazil with more than 270 thousand students spread in nineteen states around the country. It offers technical undergraduate courses, bachelor and teaching degrees and graduate courses in the face-toface, distance learning and semi distance learning modes. Undergraduate courses are focused on the Brazilian labor market. The curricula of all courses are integrated in all colleges. In order to study there, students must write an essay and take an entrance examination test with questions on general topics. All the courses charge fees but in some cases scholarships are available for students coming from the public educational system. Students can also apply for university credit.

\subsubsection{Business Administration Course at Private University}

As in the Public University investigated, the Administration Course in the Private University also lasts eight

\footnotetext{
${ }^{1}$ In the end of 2014 the program was renamed Languages without Borders to include other foreign
} languages though most of its actions are still concentrated in the development of English in Brazil. 
semesters and the mandatory courses offered are practically the same, perhaps with a different name but regarding the areas of financial math, statistics, general administration theory, basic accounting, human resources, marketing administration, macro and micro Economics.

In the first semester the mandatory courses are: Foundations of Social Sciences, Academic Writing, Administration and Market, Introduction to Administration, Business Math, Organizational Psychology. In the second semester the courses are Basic Accounting, Foundations of Economics, Organizational Analysis, Organizational Communication and General Theory of Administration. The courses offered in the third semester are Process Management, Foundations of Corporate Law, Applied Statistics, Financial Math, Micro Economics and Costs Accounting. In the fourth semesters the courses are: Labor and Retirement Law, Foundations of Foreign Trade, Supply Chain Management, Statistical Analysis, Managerial Accounting and Macro Economics. In the fifth semester the courses are: Marketing Administration, Human Resources Administration 1, Analysis of Financial Statements, Tax Law and Operation and Production Administrations. The courses of the sixth semester are: Market Research, Ethics and Social Responsibility, Research Methodology, Human Resources Administration 2, Information Systems Administration and Financial Administration. In the seventh semester the courses are: Strategic Management, Quality Management, Corporate Budgeting, Special Topics in Administration and Supervised Administration Practicum. In the last semester the courses are: Project Management, Corporate Games, Financial Market, and Quantitative Methods for Decision Making, Research Paper in Administration, Administration of New Businesses and Competence Management.

\section{ANALYSIS}

This analysis will be divided in two parts. The first part will analyze the internationalization policies and actions (or the lack of it) in the public and private universities investigated and the second part will look at the curricula of the Business Administration Course in these two contexts so as to verify whether these policies and curricula are conducive of social capital construction for the business administrators to work in a globalized world through the inclusion of English courses and the access to information, research and courses on globalization.

Regarding the internationalization policy of the public university investigated, there is only one program for academic mobility IN for undergraduate courses, namely, the PEC-G Program for Portuguese speakers. That type of mobility is limited since the number of academics who speak Portuguese and can thus join the program is much smaller than the number of academics who speak English or Spanish, for example. What is more serious, the relevance of this academic mobility to the construction of social capital through the exchange of research between the participating countries seems to go in only one direction since only the countries which are coming to Brazil seem to benefit from this type of mobility. Most of the universities which can join this program are ranked in a worse position than the Brazilian institutions. Thus, programs such as the PEC-G program for mobility IN can be said to be more conducive of the construction of social capital of academics in countries outside Brazil since the academics in these countries come from institutions ranked in a lower position than those which joined the program in Brazil. In terms of international academic mobility OUT, there are more programs and investment in this type of mobility such as in the Science without Borders (CsF) program.

Taking these two programs in consideration, it is possible to suggest that although the university investigated has an internationalization policy, most programs are of the OUT type given the difficulty to receive foreign students because of the language barrier - all classes and tests (and practically all the sites) are in Portuguese. Moreover, the only program for academic mobility IN is not conducive of the construction of social capital of Brazilian academics. The analysis of the data suggests that the main challenge for academic mobility and internationalization of the public university investigated is the mastery of English as an international and academic language. Moreover, the analysis suggests that the motivation to go international is not driven by financial reasons (since foreign students would not have to pay fees here) but rather by the search for academic excellence. If that is the case, as we suspect, the institution investigated could benefit from the inclusion of ESP and CLIL courses both at the undergraduate and graduate levels to attract foreign academics leveling Brazilian academics as a consequence of this contact.

In the case of the private institution investigated, although the university claims to have international partners, no information is given in the site - which is only available in Portuguese - and no office for international affairs was found. Thus, the analysis of the internationalization process of the private institution investigated suggests that there is no such process underway. Moreover, the analysis shows that although the internationalization process (if there were one) could be driven by financial reasons (attracting foreign students' fees), given the size of the internal market in Brazil, there is no need to look for students outside 
the domestic language borders. The analysis of the curriculum of the Business Administration Course in the private institution confirms this suggestion since no ESP or CLIL classes were found for this course nor does the institution offer extracurricular classes in English. Finally, the analysis of student profile in the private university suggests that given the size of the Brazilian market ${ }^{2}$ and percentage of Brazilians in public and private institutions ${ }^{3}$, the motivation to go international in private institutions is almost inexistent since they have a huge internal market to explore.

Regarding the curricula of the Business Administration Course in the two institutions, it is possible to suggest that both curricula are similar, rigid and limited in the sense that they are focused on the Brazilian market and do not offer possibilities for student flexibility and autonomy nor international development or integration of the knowledge built during the course with the international scenario and globalized market. Moreover, the universities do not offer CLIL, ESP or English as a foreign language courses for the Business Administration Course thus preventing students from being integrated with the international market and scientific publications through the mastery of the international and scientific language and global content.

\section{CONCLUSION}

The aim of this study was to reflect about the interconnectedness of globalization, the internationalization process of universities and the construction of social capital in emerging countries based on the analysis of the Business Administration Course of a public and a private university in Brazil. The study was based on the assumption that globalization affects higher education in both positive and negative ways and that the appropriation of English as an international language was necessary to drive social inclusion and agency in education in general and for the Business Administration course in particular. Another assumption of the study is that the integration of courses on international market and globalization are necessary in the Business Administration Course to form social capital to prepare future administrators to deal with the complexity and challenges of a globalized market.

In order to carry out the reflection proposed here, the internationalization policies and curricula of two Business Administration Courses in two universities in Brazil were analyzed. The analysis of the internationalization policies in the Public University investigated shows that although the university has an internationalization office and agenda, most of the exchange programs are of the OUT type in the sense that the university prepares students to go abroad but is not yet prepared to receive foreign students because of the language barrier. Moreover, the analysis showed that the programs for academic mobility IN were not conducive of social capital construction at least in Brazil. Taken these two types of programs for academic mobility in the public institution investigated, it is possible to suggest that the motivation to go international is driven by a search for academic excellence in public institutions and the main obstacle for this achievement is the language barrier.

Regarding the private institution investigated, no internationalization office or policy was found suggesting that private institutions, which could be motivated to go international by the attraction of foreign students' fees, are perhaps more interested in the domestic market, given its size in Brazil. As it is, the private language institution is even less conducive of social capital construction through the inclusion of students in the globalized world than the public institution investigated and that can be accounted for as a negative effect of globalization in higher education since most students in Brazil are enrolled in private universities.

In what concerns the analysis of the curricula of these institutions, neither of the curricula analyzed offer courses in English and only the public institution offers English as a foreign language classes for the academic community as extracurricular courses. Moreover, the curricula analyzed do not offer globalization and international market courses to prepare business administrators to work in a globalized world. Taken together, the data in this study suggest that the curricula investigated do not aim at developing critical thinking skills or the construction of social capital of future administrators to work in the globalized world.

This study was motivated by the question of whether there is a connection among globalization, internationalization and education. The analysis of two Business Administration Courses in an emerging country suggests that there is a connection among globalization, internationalization and education and we understand this connection to be social capital that can be materialized in the access to international markets

\footnotetext{
${ }^{2}$ Brazil is the world's sixth largest economy.

${ }^{3}$ As previously stated in the introduction to this paper, around two thirds of Brazilian university students are enrolled in private universities and though the percentage of Brazilians in higher education is small (around $3,5 \%$ ), the total population (over 200 million) is large enough to guarantee a constant domestic demand without having to look for international students.
} 
and information. Moreover, the analysis in this study suggests that the institutions analyzed still have to include English as an international or academic language and globalization topics in their curricula so as to form social capital and critical thinkers. Thus, the analysis of two university courses suggests that the context investigated is not conducive of social capital construction because it does not connect globalization, internationalization and education.

\section{REFERENCE LIST}

A.Mcgrew. Globalization and global politics. In J. Baylis; S. Smith and P. Owens (Orgs.), The Globalization of World Politics, Oxford, $4^{\text {th }}$ edition, 2008, p.20.

J.C. Shin; U. Teichler. The Future of University in the Post-Massification Era: a Conceptual Framework. In J.C. Shin and U. Teichler (Eds.), The Future of the Post-Massified University at the Crossroads: Restructuring Systems and Functions. Springer, 2014. p.3-4

J.C. Shin; U. The University as an Institution of Higher Learning: Evolution or Devolution? In J.C. Shin and U. Teichler (Eds.), The Future of the Post-Massified University at the Crossroads: Restructuring Systems and Functions. Springer, 2014. p.17

M. Warschauer, and T. Matuchniak. New technology and digital worlds: Analyzing evidence of equity in access, use, and outcomes. Review of Research in Education, 34(1), 179-225. 2010.

M. Warschauer. Social capital and access. Universal Access in the Information Society, 2(4). 2003.

K. Finardi, G. Prebianca and F. Momm. Tecnologia na Educação: o caso da internet e do inglês como linguagens de inclusão. Cadernos do IL, n. 46, p. 193-208, 2013.

D. Graddol. English Next: why global English may mean the end of "English as a foreign language". The English Company (UK) Ltd. British Council. pp.132. 2006. Available at http://www.britishcouncil.org/learning-research-english-next.pdf.

M. Warschauer. The Changing Global Economics and the Future of English Teaching. Tesol Quarterly. Vol.3 4, No. 3, Autumn, 2000.

U. Smit and E. Dafouz. Integrating content and language in higher education: an introduction to Englishmedium policies, conceptual issues and research practices across Europe. AlLA Review 25. p.1-12. 2012.

D. Neubauer. The University in the Context of Continuing Globalization. In J.C. Shin and U. Teichler (Eds.), The Future of the Post-Massified University at the Crossroads: Restructuring Systems and Functions. Springer, 2014. 